\title{
Probabilistic calculation in terms of deformations of the formations consisting of compacted overburden of Quarternary rocks
}

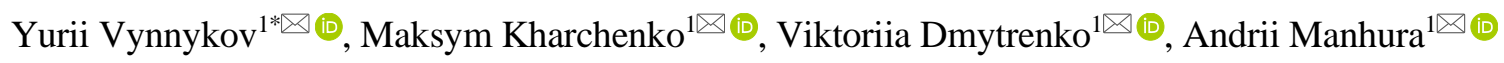 \\ ${ }^{1}$ National University "Yuri Kondratyuk Poltava Polytechnic", Poltava, 36011, Ukraine \\ *Corresponding author: e-mail mangura2000@gmail.com, tel. +3806693455030
}

\begin{abstract}
Purpose is to study the effect of a stress-strain state (SSS) of rock mass on statistical dispersion of deformability characteristics of the compacted overburden; to develop modeling methods of dispersion of random values (RV) influence of subsoil material characteristics; and to analyze their SSS modeling using a finite-element method as well as simulation modeling.

Methods. The following has been applied: the tested methods of experiment planning theory; methods of rock mechanics; methods of mathematical statistics and probability theory; simulation using Monte Carlo method; and finite-element method (FEM) using elastic-plastic model to simulate SSS of artificial rock masses.

Findings. Statistic parameters of the distribution of RVs of both analytical and boundary resistances of the compacted overburden have been obtained as well as subsidence of plates (bases) on beddings, and their relative irregularities. Statistic parameters and regularities of plate subsidence have been identified using numerical SSS simulation of beddings, and simulation by means of Monte Carlo method. It has been determined that there is a probability of origination of a nonlinear stage of a basis deformation in addition to a linear one. The fact can be explained by variability of the compacted rock characteristics as well as random nature of loads on the bases. It has been defined that probability failure of the basis on a bedding from 1 st boundary condition is allowable since safety characteristic is $\beta>3-4$; in terms of relative irregularity criterion, their subsidence on a one layer bedding achieves $10 \%$ when its boundary value $(\Delta S / L)$ is $u=0.002$ and $3 \%$ when its boundary value $(\triangle S / L)$ is $u=0.004$; however, in the context of a multilayer bedding, the values are only $0.02 \%$, and $0.0006 \%$ respectively.

Originality. It has been identified that determination of deformation of the beddings, belonging to overburden Quarternary rocks, should take into consideration the determined regularities of distribution of physiomechanical characteristics of the compacted soil in the process of analytical numerical simulation, and in the context of finite element method using elastic-plastic model.

Practical implications. Possibility to utilize overburden Quarternary rocks as well as their mixtures has been proved while using them as a material of soil beddings for buildings and structures; and methods have been developed to calculate artificial formations on the basis of the compacted overburden taking into consideration statistic parameters of distribution of their physiomechanical characteristics.
\end{abstract}

Keywords: overburden, soil bedding, multifactor analysis, internal friction angle, specific cohesion, deformation modulus, distribution law, subsidence

\section{Introduction}

Urbanization has originated a tendency to develop territories used to be considered as unusable for erection of buildings and construction due to technical difficulties inclusive of the territories with complex engineering and geological as well as hydrogeological conditions. On the other hand, the huge territories, applied for agriculture and forest ranges, are covered by mining and processing waste (i.e. disperse rocks) containing poor ore; washery refuse including spoil banks, waste piles of open pits and ore mines extracting sulfide ores of non-ferrous metals, oxide ores and iron silicates of ferrous and alloying metals; middlings and tailings by mining and processing plants; overburden etc.
In terms of the conditions, geotechnical engineering proposes to develop artificial bodies with better building performance to compare with natural soil. In this context, solving the problems, connected with industrial waste utilization and decrease in the cost of ground beddings, involves the necessity to study the use of overburden rocks, left after mineral mining, and their mixtures as the material to manufacture artificial bases [1].

Currently, numerous indicative examples of artificial geoformations are known. They have been erected by means of the compacted mining and processing waste; overburden Quarternary rocks and their mixtures; and even ash waste left after coal and oil shale combustion [2]. 
At the same time, the compacted formations are characterized by non-uniformity; random dispersion of values of rock (soil) characteristics; regularities of medium consolidation in terms of depth etc. may be considered as its parameters. The parameters depend upon a type of the artificial basis material, its natural characteristics, and process conditions of its erection. The available normative approach can only evaluate consolidation quality ignoring practically nonuniformity parameters of the piled formations. Calculation methods for soil beddings are deterministic ones [3]; they cannot take into consideration actual dispersion of values of physiomechanical characteristics of the compacted rocks which results in the inadequate safety margins, and deformability in the process of their erection [4].

Sufficient calculation accuracy as well as determination of actual SSS basis parameters should involve various nonuniformity types [5] being common for real formations owing to the diversity of their composition and structure; soil polydispersity, multiphase nature, and compoundness; nature of internal ties [6]; and effect of engineering and geological processes. Dispersion of physiomechanical characteristics; medium consolidation regularities in terms of depth; and anisotropy of mechanical characteristics are considered as non-uniformity parameters of the compacted rock (soil) [7]. Features of soil non-uniformity should be taken into consideration to approach the artificial bases models to their real SSS.

Hence, the research topic is actual from the viewpoint of overburden utilization as the material for artificial bases; widening of technical standards to design and erect soil beddings; and involving of non-uniformity of soil parameters for artificial bases of buildings and structures.

\section{Analysis of the recent research}

Mainly, the dispersion of values of characteristics of both natural and compacted soil formations is greater to compare with other materials used for engineering structures. In terms of the approach, involving non-uniformity features of the compacted rocks (soils), analytical models single out four groups [8].

Group one develops a possibility to obtain the listed characteristics of the compacted basis soil. Group two describes the non-uniformity of artificial model with the help of probabilistic models where the soil is a discrete model rather than a continuous one [1]. Group three explains how a model of the random and non-uniform basis applies modification of Winkler type where normally distributed RVs are the basis rigidity coefficient [9]. Group four uses a probabilistic approach [10].

Deterministic nature of group one models is its disadvantage [1]. Methods of group two did not obtain MSE solutions; the fact complicates their use. Methods of group three solve the problems in the simplified manner. Ignoring of soil compaction features in the process of bases erection (the problems have been solved by group one) as well as nonavailability of the algorithms to develop software systems with the use of FEM are the disadvantages of group four.

It should be noted that probabilistic approach, i.e. socalled simulation with the use of Monte Carlo method has been tested sufficiently while modeling different types of 3D-problems of FEM of SSS for non-uniform natural and artificial formations [11]-[14]. Authors of the research consider that such solutions may be directed to a wide range of geotechnical situations to reduce uncertainty and risks connected with spatial variability of soils (rocks). Hence, to introduce stochastic models of artificial bases into engineering practices, it is necessary to identify statistic parameters of strength and deformability characteristics of the compacted soil; analyze the factors effecting the nature of their RV distribution; and study the regularities being available within the artificial formations during their operation.

A typical example took place while erecting metallurgical plant Vorskla Stal under the technology of Austrian Company Voest Alpine Industrieanlagenbau with the provision of both technical and environmental safety of natural resources. Quarternary deposits, belonging to low-viscosity overburden (mainly, fine sand and moderately coarse sand) from Yerystivskyi and Lavrykivskyi ore quartzite deposits in the neighbourhood of Horishni Plavni Town (Poltava Region).

Laboratory research and full-scale studies have been performed [2] to obtain more than $3000 \mathrm{RV}$ physiomechanical characteristics of the compacted soil, overburden and its mixtures; effect of technological parameters on the dispersion of the values has been identified; correctness of a normal distribution law for physical characteristics of soil and bedding types has been substantiated statistically. Adequacy of polynom exponential distribution law has been substantiated in terms of mixtures; adequacy of log normal distribution law has been substantiated in terms of deformational module of the compacted soils and mixtures; adequacy of a normal law has been substantiated in terms of internal friction angle; adequacy of a log normal law has been substantiated in terms of specific cohesion; and adequacy of an exponential distribution law has been substantiated in terms of specific penetration resistance.

Comparison of the variation coefficients of physiomechanical parameters of the compacted soil and natural one has been proved that use of low-viscosity overburden as well as mining and processing waste for a bedding makes it more uniform to compare with nature. Soil type and content of impurities in it is the technological factor influencing heavily the variability of a new formation; the number of roller passages on the same track as well as vibration or static mode of the equipment has lesser influence; and a layer thickness before compacting is the least influence. Variation coefficients of density values of a soil skeleton are $2-44 \%$; watercontent coefficients are $23-36 \%$; coefficients of specific soil weight are 4-4.6\%; coefficients of deformational modulus are $33-57 \%$; internal angle friction coefficients are $11 \%$; specific cohesion coefficients are $25 \%$; and coefficients of specific penetration resistance are $57 \%$ [8].

Data, coinciding qualitatively in terms of laboratory research and full-scale studies, have been obtained for artificial formations consisting of rocks. It goes without saying that values of their variation coefficients differ [15].

Normal and log normal laws of RV distribution take place too [16]-[18] as well as multivariant normal RV distribution as for the strength parameters of a clay soil in the context of problems intended to evaluate resistivity of the formation slopes [19]-[21]. The approaches have been implemented while solving 2D FEM problems with the use of a probabilistic procedure.

That is why the research objective is to study the effect by SSS of artificial formation on the statistic dispersion of deformability characteristics of the compacted soil; develop methods to simulate effect of dispersion of RV characteristics of bases material; and analyze their SSS with the help of FEM simulation using elastic-plastic model as well as service-simulating test. 


\section{The research methods}

Stress and strain of plate bases are space-time random fields which characteristics depend upon non-uniformity of soil formation as well as upon spatial and time fluctuations of external loads. Hence, SSS determination of both natural and artificial bases is the problem of probabilistic and statistic analysis. That is why statistic simulation (using Monte Carlo method; approximating polynom; and approaches by O. Lychiov and V. Chyrkov), and FEM of SSS simulation for artificial bases performed involving a spatial model of Ansys 11.0 (Ansys Structural) software system as a static nonlinear problem with the help of its Ansys Probabilistic Design System (PDS) subprogram using Drucker-Prager elastoplastic model, Monte Carlo method, and experimental results by [2] authors concerning regularities of RV distribution of physiomechanical characteristics of the compacted overburden.

The soil model applies sufficiently tested soil mechanics hypotheses [1]:

1) within one finite element, soil is considered as a uniform isotropic medium;

2) no strain can disturb uniformity of the formation;

3 ) any change in the strain type is a nonlinear one;

4) vectors of the main plastic strains (and their velocities) as well as the main stresses in the context of the complex stress are assumed as coaxial ones;

5) load is simple (components of stress deviators increase in proportion to one parameter);

6) coaxiality of stress and strain tensors is preserved.

Values of the five key parameters have been assumed to apply correctly Drucker-Prager model: deformational modulus $E$; Poisson's ratio $v$; angle of internal soil friction $\varphi$; its specific cohesion $c$; and dilatancy angle $\Delta *$. Within each step, iteration process involved following stages:

1) putting of a force vector on a "failure zone" (i.e. the part of a calculation area where strength condition is broken in terms of a linear solution to transfer it to a physically possible stress state; certain part of the zone is separated;

2) applying of forces within the same points (the forces are applied to the system but in the direction being opposite to the initial one).

Ansys 11.0 system has two probabilistic calculation methods, i.e. response surface method making it possible to reduce simulation time by $20 \%$ if the response surface is smooth and continuous; and Monte Carlo simulation method being the most flexible since it does not impose constraints on the response surface type. The two options are available for Monte Carlo method, i.e. Latin Hypercube Sampling, and Direct Monte Carlo Sampling. Response surface method also has two options - Central Composite Design and BoxBehnken Matrix Design.

In terms of random input variables (i.e. RVs, "drivers"), which can be represented by the model geometry and physiomechanical parameters of the material and load, it is possible to specify for them corresponding distribution laws as well as statistic parameters. Among other things, it is possible to use normal Gaussian (GAUS); the truncated Gaussian, (TGAU), lognormal option 1 (LOG1); lognormal option 2 LOG2); triangular (TRIA); uniform (UNIF); exponential (EXPO); beta (BETA); gamma (GAMM); and Weibull (WEIB) distribution laws. LOG1 and LOG2 differ in the following: in case one, mathematical expectation is specified as well as standard deviation in terms of the automated calcu- lation of the value logarithms; and in case two, logarithm of mathematical expectation and a standard deviation is specified at once. Hence, rather solid library of distribution laws and calculation methods helps perform correctly probabilistic calculations of both natural and artificial formations.

Response surface as well as cumulative distribution function and histogram of the random output parameters (RPs) may be obtained as the probabilistic calculation results. By the way, it is impossible to specify more that $5000 \mathrm{RVs}$ and RPs in Ansys 11.0. Moreover, Ansys 11.0 system helps simulate complex models of finite elements, and perform detail representation of the simulation results. The calculation is fully automated; and it is based upon numerical methods. In this context, such a geometrical model is developed which dimensions prevent from its boundary effect on the calculation results [1], [10].

Calculation area of the problem in terms of 3D formulation (i.e. 8 binodal finite elements SOLID 45) with plates on them is one-half parallelepiped relative to symmetry axis (Fig. 1) to reduce their analysis time. For collaboration of the plate and formation, their contact surface should be "sewn together" using Booleans option.

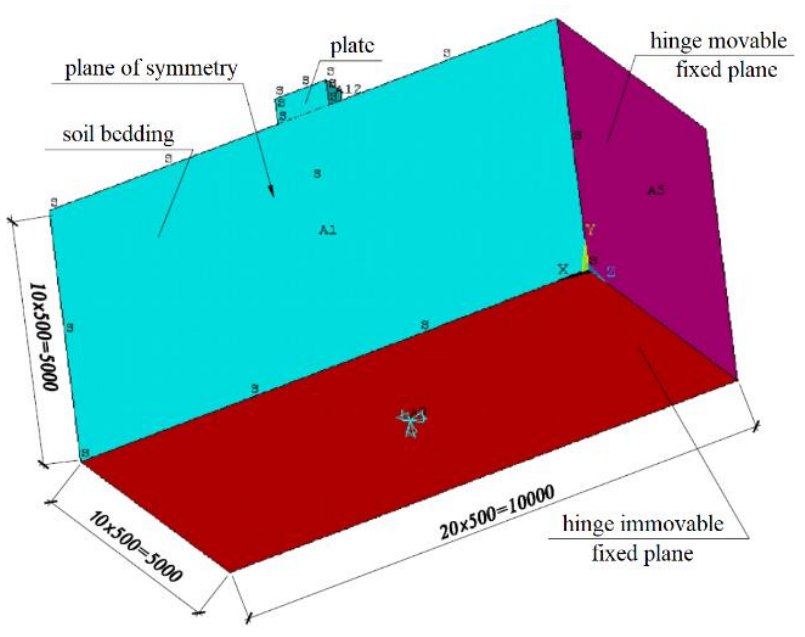

Figure 1. Calculation scheme of a FEM plate on a soil bedding in terms of spatial formulation

Geometry of the calculation area has been determined in such a way:

1) side boundaries of a square calculation area are assumed respectively on a vertical symmetry axis and at a sufficient distance from a side boundary of the plate to minimize effect by the latter. Horizontal displacements, stress concentration, and soil compaction within the stress-external boundary of the calculation area contact are prohibited (relying upon practices, to fulfill the condition it is sufficient to assume the calculation area side as that being no less than $10 \mathrm{~b}$ where $b$ s the plate width);

2) upper horizontal boundary of the area is located at the bedding surface level; and

3) lower horizontal boundary is within the bedding boundaries being no less than the compacted layer depth [1].

After geometry of the calculation area, and parameters of the model material are assumed and its automatic division on elements are performed, boundary conditions are determined. The boundary conditions correspond to nature features of the basis and plate conditions under stress: each node within a 
lower boundary of the calculation area is fixed immovably; and nodes of side boundaries could not displace horizontally. External stress is applied as that one distributed according to upper edge of the plate. All the physiomechanical characteristics, describing the soil formation, are RVs. They were assumed as variables which determinated values were assigned to them at stage one of the calculations. The plate was assumed as the reinforced-concrete one with the stable linear characteristics (i.e. elasticity modulus is $E=20 \cdot 10^{6} \mathrm{kPa}$; $v=0.2$; and $\gamma=25 \mathrm{kN} / \mathrm{m}^{3}$ ).

Since FEM calculation was performed involving plastic soil characteristics, the equation becomes nonlinear ones. Thus, the problem was solved using incremental-iterative procedures.

Iteration procedure relies upon the accelerated method of initial stresses. Standard iteration number is 5 to 10 ; maximum number is 50. Standard value of allowable error is 0.03 . After the problem is solved in terms of the determinated formulation using Ansys 11.0, sampling points are generated in the space of input variables with the help of Monte Carlo method. Simulation number is $10^{4}$. The earlier results have been applied [2] to carry out statistic analysis of distribution of bases (i.e. rigid plates) subsidence as well as their relative non-uniformity. Moreover, distribution functions of the values as random ones have been determined in addition to their statistic parameters. Adequate distribution laws and statistic parameters, identified during the full-scale experiment, have been specified of RVs of physiomechanical characteristics. Among other things, a normal distribution law with $v=4 \%$ variation coefficient was specified for RVs of specific soil weight; $\log$ normal distribution law with $v=40 \%$ was specified for PVs of deformational modulus $E$; and normal, and $\log$ normal distribution laws were specified for internal friction angle $\varphi$ and specific cohesion $c$ respectively. Value variation coefficient $\varphi$ is $v=11 \%$; and $c-v=25 \%$.

The following has been assumed as the determinated parameters. Square plate in the plane with $1 \times 1 \mathrm{~m}$ dimensions and $d=1 \mathrm{~m}$ grounding depth; average pressure under its bottom is $p=274 \mathrm{kPa}$. The basis is in the form of the compacted bedding (fine and dusty sand; uniform; with plastic sandy loam admixtures) having average values of physiomechanical characteristics (specific weight is $\gamma=18.9 \mathrm{kN} / \mathrm{m}^{3}$; internal friction angle is $\varphi=31^{\circ}$; specific cohesion is $c=22 \mathrm{kPa}$; and deformational modulus is $E=19.4 \mathrm{MPa}$ ). Moreover, following prerequisites have been specified: deformation effect of the bedding basis is ignored; the formation under compression is within the bedding boundaries; and ground water level has no effect on the plate subsidence.

It has been determined as a result of the calculation of the plate on bedding that basis subsidence $S$ is the required function of random arguments. Analytical methods (i.e. linearization method; Monte Carlo method; Lychiov and Chyrkov method) have helped obtain statistic parameters of distribution of RVs of both analytical and boundary resistances of the compacted soil; $S$ subsidence of bases on beddings; and their relative non-uniformity. Statistic parameters as well as laws of distribution of RVs of $S$ bases subsidence have been determined using numerical simulation of SSS of FEM of beddings inclusive of elastoplastic soil model; and imitational simulation by means of Monte Carlo method involving distribution laws of RVs of physiomechanical characteristics of soil beddings deduced from the experiments. Rejection probability has resulted from the statistic analysis of $S$ subsidence distribution of artificial bases as well as their relative non-uniformity.

\section{Results and discussions}

It has been indentified that distributions of RVs of both analytical and boundary resistances of the compacted soil can be approximated quite correctly with the help of a normal Gauss law. Variation coefficient of RVs of the analytical resistance of the compacted soil is $v=21.8-36.3 \%$; variation coefficient of the boundary resistance is $v=34.4-37.5 \%$. Table 1 demonstrates other statistic parameters.

In the context of the determinated strategy, a probabilistic approach to determine $S$ subsidence of a basis on bedding has helped determine a probability of both linear and nonlinear stages of a basis deformation at a pressure not exceeding analytical resistance of the compacted soil under the basis bottom. Hence, elastic deformations experience their development along with the plastic ones with no separation of their zones. The abovementioned is stipulated by nonuniform characteristics of the compacted soil as well as by random nature of loads and effects on bases.

Table 1. Statistic distribution parameters of RVs of both analytical and boundary resistances of the compacted bedding soil

\begin{tabular}{|c|c|c|c|}
\hline \multirow[b]{2}{*}{ Parameters } & \multicolumn{3}{|c|}{ Simulation methods } \\
\hline & Polynom & $\begin{array}{l}\text { Monte } \\
\text { Carlo }\end{array}$ & $\begin{array}{l}\text { By Lychov } \\
\text { and Chyrkov }\end{array}$ \\
\hline \multicolumn{4}{|c|}{$\begin{array}{c}\text { Analytical resistance of the compacted soil } \\
R / \text { boundary resistance of the compacted soil } p_{u}\end{array}$} \\
\hline \multirow{2}{*}{$\begin{array}{l}\text { Mathematical } \\
\text { expectation, } \mathrm{kPa}\end{array}$} & $268.3 /$ & $273.5 /$ & $276.2 /$ \\
\hline & 1208.5 & 1606.3 & 1660 \\
\hline \multirow{2}{*}{ Standard, kPa } & $59.6 /$ & $59.6 /$ & $102.8 /$ \\
\hline & 442.3 & 550.3 & 621.1 \\
\hline \multirow{2}{*}{ Variation coefficient, $\%$} & $22.2 /$ & $21.8 /$ & $36.3 /$ \\
\hline & 36.6 & 34.4 & 37.5 \\
\hline \multirow{2}{*}{ Asymmetry } & $0.10 /$ & $0.10 /$ & $0.45 /$ \\
\hline & 0.65 & 0.52 & 0.41 \\
\hline \multirow{2}{*}{ Excess } & $-0.10 /$ & $-0.10 /$ & $-0.49 /$ \\
\hline & -0.22 & -0.39 & -0.87 \\
\hline \multirow{2}{*}{$3^{\text {rd }}$ order moment } & $-13474 /$ & $84614 /$ & 401453/ \\
\hline & $5.6 \cdot 10^{7}$ & $8.4 \cdot 10^{7}$ & $9.1 \cdot 10^{7}$ \\
\hline \multirow{2}{*}{$4^{\text {th }}$ order moment } & $4.3 \cdot 10^{7} /$ & $3.4 \cdot 10^{7} /$ & $2.3 \cdot 10^{8} /$ \\
\hline & $1.1 \cdot 10^{11}$ & $2.4 \cdot 10^{11}$ & $3.1 \cdot 10^{11}$ \\
\hline \multirow{2}{*}{ Median, $\mathrm{kPa}$} & $267.3 /$ & $269.2 /$ & $269.5 /$ \\
\hline & 1146.4 & 1522.2 & 1558.8 \\
\hline \multirow{2}{*}{ Minimum, $\mathrm{kPa}$} & $97.8 /$ & $97.8 /$ & 107.3/ \\
\hline & 473.6 & 354.5 & 666.1 \\
\hline \multirow{2}{*}{ Maximum, kPa } & $450.7 /$ & $450.7 /$ & $533.5 /$ \\
\hline & 2552.5 & 3056.1 & 2986.3 \\
\hline
\end{tabular}

In terms of the multilayer bedding, subsidence variation coefficient value $v_{s}$ is less than in terms of the one-layer bedding despite mathematical subsidence expectation is 2.4 times more. The decreased $v_{s}$ coefficient for multilayer artificial formation can be explained by the fact that the value is a result of composition of numerous random subsidence variabilities in certain mutually overlapped layers.

$v_{s}$ coefficient also increases along with the increased nonuniformity of stratifications. Moreover, $v_{s}$ values depend upon layer thickness $h$ as well as the ratio of deformation moduli $E$ within them.

$v_{s}$ increases along with the increased stratification nonuniformity; among other things, it concerns greater compressibility of upper layers to compare with the bottom ones as well as the increased ratio between the deformation moduli within them. A technique applied to erect bedding with varying degree of compaction of its layer reduces variability of the basis subsidence on it. 
In terms of edge state 1 , rejection probability of the bases on a soil bedding is considered as acceptable since safety characteristic, proposed by $\mathrm{O}$. Rzhanitsyn, is $\beta=4.82>3 \ldots 4$.

In terms of edge state 2 , rejection probability takes place according to non-uniformity criterion of subsidence of bases on one-layer bedding. It is $10.32 \%$ (if $\left.(\Delta S / L)_{u}=0.002\right)$ and $3 \%\left(\right.$ if $\left.(\triangle S / L)_{u}=0.004\right)$.

In the context of multilayer bedding, the values are 0.02 and $0.0006 \%$ respectively.

Table 2, Figures 2 and 3 demonstrate results of the analysis concerning distribution and statistic parameters of RVs of subsidence of the basis on soil bedding.

Table 2. Comparative analysis of statistic characteristics of bases subsidence on soil beddings in terms of analytical and numerical probabilistic calculations

\begin{tabular}{lcc}
\hline \multirow{2}{*}{ Characteristics } & \multicolumn{2}{c}{$\begin{array}{c}\text { Subsidence of a basis bedding in terms } \\
\text { of randomness of both linear and } \\
\text { nonlinear stages of the soil deformation }\end{array}$} \\
\cline { 2 - 3 } & \multicolumn{2}{c}{ One-layer bedding } \\
\cline { 2 - 3 } Mathematical & 0.83 & Analytically \\
expectation, cm & 0.39 & 1.35 \\
Standard, cm & 47 & 0.54 \\
Variation coefficient, \% & 2.2 & 40 \\
Asymmetry & 9.17 & - \\
Excess & 0.15 & - \\
Dispersion & 0.02 & - \\
Minimum, cm & 4.23 & 0.65 \\
Maximum, cm & & 2.65 \\
Failure probability & & $\left(S_{u-}-S_{a v}>>5 \sigma\right)$ \\
(excess in $\left.S>S_{u}=10 \mathrm{~cm}\right)$ &
\end{tabular}

Namely, Figure 3, a shows probability of plastic component of deformations under a plate bottom if the abovementioned random physiomechanical bedding characteristics are assumed. As it is understood from Figure 3b, distribution of RVs of subsidence of a plate on soil bedding can be approximated quite correctly using a normal Gauss law. In this context, minimum subsidence value is $S_{\min }=6.5 \mathrm{~mm}$; maximum value is $S_{\max }=26.5 \mathrm{~mm}$; and average value is $S_{a v}=13.5 \mathrm{~mm}$. In this case, maximum coefficient of subsidence variation is $44 \%$.

As Table 2 demonstrates, the result agrees adequately with analytical probabilistic calculation of the basis bottom in terms of randomness of linear and nonlinear stages of soil deformation. In this context, rejection probability $\left(S>S_{u}=10 \mathrm{~cm}\right.$ excess) is minor since interval is $\left(S_{u}-S_{a v}\right)>5 \sigma$ [4].

Hence, it is possible to generalize that FEM simulation of SSS of artificial bases in terms of probabilistic formulation (using Monte Carlo method) is quite reliable proving the possibility that analytically substantiated probability of both linear and nonlinear stages of soil deformation is available even if pressure under a plate (basis) bottom does not exceed analytical pressure of the compacted soil in terms of the determinated approach.

Hence, FEM in terms of probabilistic formulation describes correctly the real processes taking place within the soil beddings during their operation. According to the numerical FEM simulation using software system Ansys 11.0 as well as its Probabilistic Design and Monte Carlo method in terms of iteration number $10^{4}$, and probabilistic formulation, correctness of the normal distribution law application has been proved to describe RVs of the rigid plate (basis) subsidence on the onelayer soil bedding with $40 \%$ variation coefficient of the values. (a)

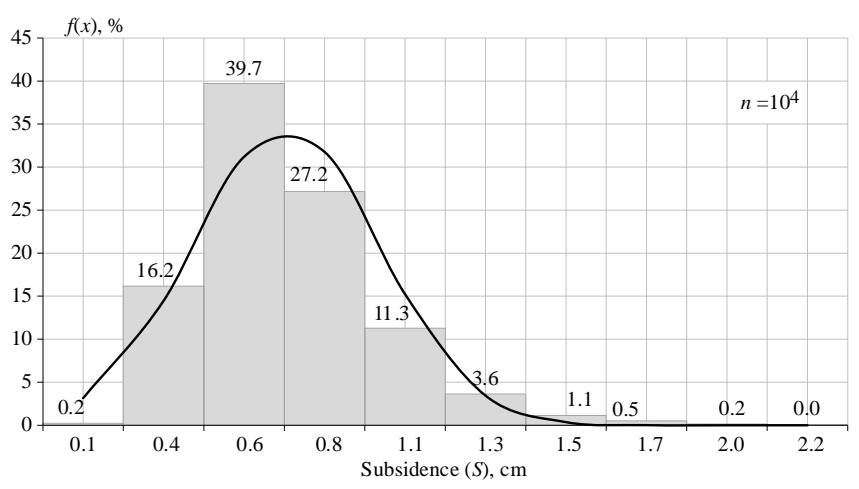

(b)

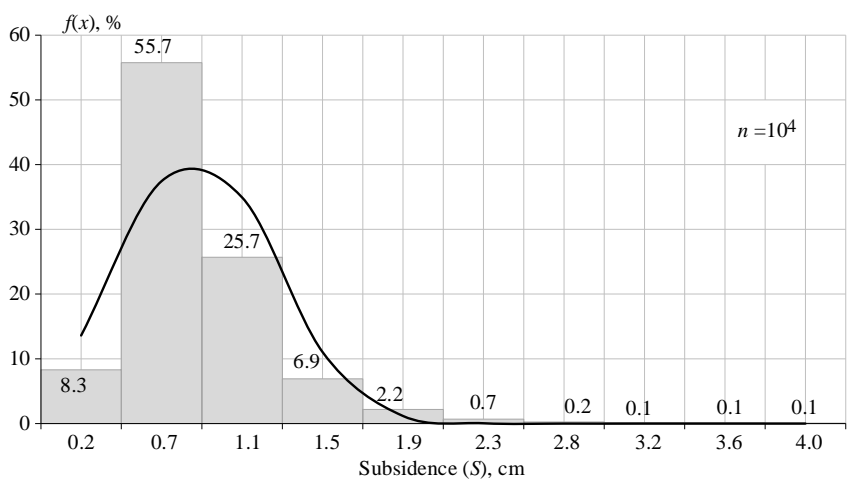

(c)

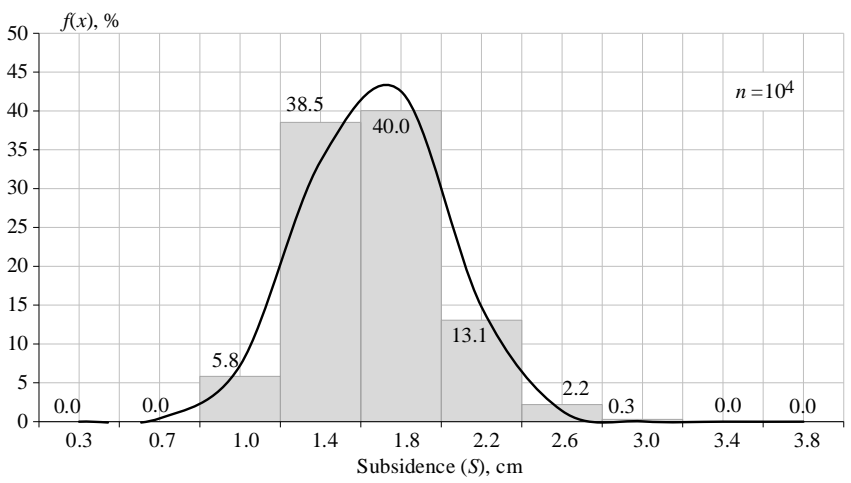

(d)

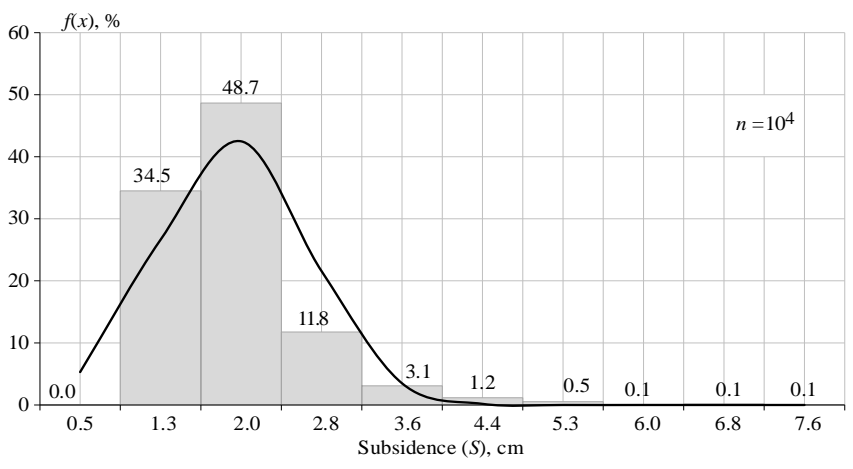

Figure 2. Graphs of distribution of RVs of a plate subsidence on a soil bedding resulting from statistic simulation using: (a) one-layer bedding at a linear stage of the basis deformation; (b) one-layer bedding involving boundary randomness of linear bottom deformation; (c) multilayer bedding at a linear stage of the basis deformation; (d) multilayer bedding at a linear stage of the basis deformation; $f(x)$ is frequency; and $n$ is the number of $R V s$ 
(a)

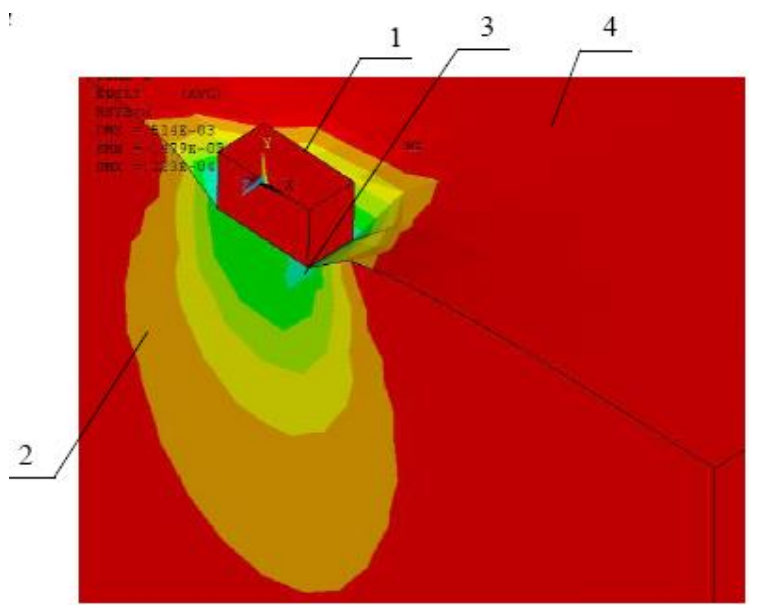

(b)

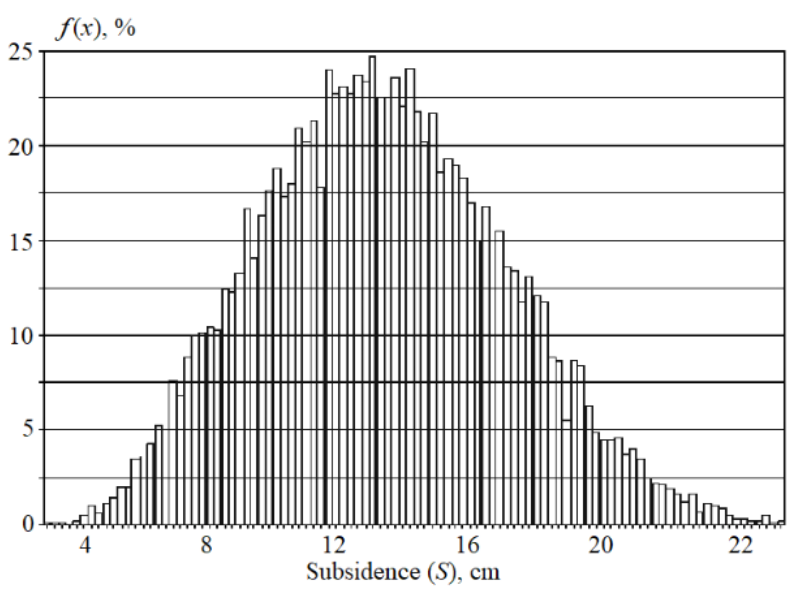

Figure 3. Results of numerical FEM simulation of SSS of a rigid plate (basis) on bedding in terms of probabilistic formulation: (a) deformation distribution within soil formation; (b) histogram of distribution of $R V s$ of basis once on a one-layer bedding; 1 -rigid plate (basis); 2 -distribution of deformations (stresses) within soil; 3 -zone of plastic deformation origination; 4 -fragment of the compacted soil formation

FEM simulation of SSS of artificial bases, using Monte Carlo method in terms of iteration number $10^{4}$ and probabilistic formulation, shows that the probabilistic availability of both linear and nonlinear stages of soil deformation describes adequately the real processes taking place in beddings while their loading.

FEM simulation of SSS bases with the use of elastoplastic model and Monte Carlo method in terms of iteration number $10^{4}$ describes correctly the bedding deformation. As for the multilayer bedding, values of subsidence variation coefficient $V_{s}$ are less than those for one-layer bedding despite mathematical subsidence expectation are 2.4 times more. $V_{s}$ coefficient increases along with the increased stratification nonuniformity. Among other things, it happens if upper layers are more compressible than lower ones and deformation moduli ratio within them increase. The method to erect bedding with different compression degrees of its layers decreases variability basis subsidence on it.

It has been identified that failure probability of bases on bedding is acceptable in terms of boundary condition 1 , since safety characteristic is $\beta>3-4$ achieving $10 \%$ if the boundary value is $(\Delta S / L)_{u}=0.002$ and $3 \%$ if $(\Delta S / L)_{u}=0.004$ in terms of a criterion of relative nonuniformity of their subsidence on the one-layer bedding. However, in the context of multilayer bedding, the values are 0.02 and $0.0006 \%$ respectively.

Hence, the calculation methods in terms of bedding deformations have been improved by means of consideration of the determined laws concerning distribution of physiomechanical characteristics of the compacted soil in terms of analytical and FEM numerical simulation using elastoplastic model; and distribution functions of RVs of design strength of the compacted soil as well as subsidence of artificial bases have been obtained in addition to their nonuniformities.

\section{Conclusions}

1. It has been determined that variation resistance coefficient of the compacted overburden of a bedding as a random value is $21.8-36.3 \%$; and boundary resistant is $34.4-37.5 \%$. Hence, in the context of a probabilistic approach (even if pressure under a plate (basis) is not higher than analytical soil pressure), there is a possibility that nonlinear stage of the basis deformation originates in addition to a linear one. The abovementioned is stipulated by the varied characteristics of the compacted rocks as well as by random nature of loads on the bases.

2. FEM simulation using elastoplastic soil model and Monte Carlo method in terms of iteration number $10^{4}$ of SSS bases corrects quite accurately deformation of artificial formation consisting of the compacted overburden. As for the multilayer bedding, subsidence variation coefficient $V_{s}$ a values are less to compare with those for one-layer bedding despite mathematical expectation of the subsidence is 2.4 times more. $V_{s}$ a coefficient increases along with the increased stratification nonuniformity. Among other things, it happens if upper layers are more compressible than the lower ones and deformation moduli ratio within them increase. The method to erect bedding with different compression degrees of its layers decreases variability basis subsidence on it.

3. It has been identified that failure probability of bases on bedding is acceptable in terms of boundary condition 1 since safety characteristic is $\beta>3-4$, achieving $10 \%$ if the boundary value is $(\Delta S / L)_{u}=0.002$ and $3 \%$ if $(\Delta S / L)_{u}=0.004$ in terms of a criterion of relative nonuniformity of their subsidence on the one-layer bedding. However, in the context of multilayer bedding, the values are 0.02 and $0.0006 \%$ respectively.

\section{Acknowledgements}

The present study would have been impossible without support by the National University "Yuri Kondratyuk Poltava Polytechnic" administration. We express our sincere gratitude for the opportunity to conduct tests in modern Laboratory of the University.

\section{References}

[1] Briaud, J.-L. (2013) Geotechnical engineering: unsaturated and saturated soils. Hoboken, United States: John Wiley \& Sons. https://doi.org/10.1002/9781118686195

[2] Vynnykov, Yu.L., Kharchenko, M.O., Dmytrenko, V.I., \& Drozd, I.S. (2019). Ubstantiation of the use conditions small-connecting quarries overburden of iron quartzite deposits for artificial bases of the mining and concentrating complex objects. Traditions and Innovations of ResourceSaving Technologies in Mineral Mining and Processing, 248-265. 
[3] Vynnykov, Y., Hajiyev, M., Aniskin, A., \& Miroshnychenko, I. (2019). Improvement of settlement calculations of building foundations by increasing the reliability of determining soil compressibility indices. Academic Journal Series: Industrial Machine Building, Civil Engineering, 1(52), 115-123. https://doi.org/10.26906/znp.2019.52.1684

[4] Elishakoff, I. (1999). Probabilistic theory of structures. Mineola, New York: Dover Publications.

[5] Rethaty, L. (1988). Probabilistic solutions in geotechnics. Amsterdam, Nederland: Elsevier. https://doi.org/10.1016/c2009-0-09654-8

[6] Vardanega, P.J., \& Haigh, S.K. (2014). The undrained strength liquidity index relationship. Canadian Geotechnical Journal, 51(9), 1073-1086. https://doi.org/10.1139/cgj-2013-0169

[7] Grimstad, G., Andresen, L., \& Jostad, H.P. (2011). NGI-ADP: Anisotropic shear strength model for clay. International Journal for Numerical and Analytical Methods in Geomechanics, 36(4), 483-497. https://doi.org/10.1002/nag.1016

[8] Zotsenko, M., Vynnykov, Y., \& Kharchenko, M. (2011). Evaluation of failure probability of soil beddings. Proceedings of the $3^{\text {rd }}$ International Symposium on Geotechnical Safety and Risk, 249-257.

[9] Denies, N., Van Lysebetten, G., Huybrechts, N, De Cock, F., Cameire, B., Maertens, J., \& Vervoort, A. (2013). Design of deep soil mix structures: Considerations on the UCS characteristic value. Proceedings of $18^{\text {th }}$ International Conference on soil Mechanics and Geotechnical Engineering, 2465-2468.

[10] Vynnykov, Y., Voskobiinyk, O., Kharchenko, M., \& Marchenko, V. (2017). Probabilistic analysis of deformed mode of engineering constructions' soil-cement grounds. MATEC Web of Conferences, (116), 02038. https://doi.org/10.1051/matecconf/201711602038

[11] Won, J.Y. (2009). A probabilistic approach to estimate onedimensional consolidation settlements. Proceedings of the $17^{\text {th }}$ International Conference on Soil Mechanics and Geotechnical Engineering, 1-5. https://doi.org/10.3233/978-1-60750-031-5-2012

[12] Leung, Y.F., Klar, A., \& Soga, K. (2010). Theoretical study on pile length optimization of pile groups and piled rafts. Journal of Geotechnical and Geoenvironmental Engineering, 136(2), 319-330. https://doi.org/10.1061/(asce)gt.1943-5606.0000206
[13] Al-Bittar, T., \& Soubra, A.-H. (2014). Probabilistic analysis of strip footings resting on spatially varying soils and subjected to vertical or inclined loads. Journal of Geotechnical and Geoenvironmental Engineering, 140(4), 04013043. https://doi.org/10.1061/(asce)gt.19435606.0001046

[14] Jiang, S.-H., Li, D.-Q., Cao, Z.-J., Zhou, C.-B., \& Phoon, K.-K. (2015). Efficient system reliability analysis of slope stability in spatially variable soils using Monte Carlo simulation. Journal of Geotechnical and Geoenvironmental Engineering, 141(2), 04014096. https://doi.org/10.1061/(asce)gt.1943-5606.0001227

[15] Liu, W.F., Leung, Y.F., \& Lo, M.K. (2017). Integrated framework for characterization of spatial variability of geological profiles. Canadian $\mathrm{Ge}$ otechnical Journal, 54(1), 47-58. https://doi.org/10.1139/cgj-2016-0189

[16] Allahverdizadeh, P., Griffiths, D.V., \& Fenton, G.A. (2015). Influence of different input distributions on probabilistic outcomes in geotechnical stability analysis. Proceedings of the XVI ECSMGE Geotechnical Engineering for Infrastructure and Development, 1549-1554.

[17] Cho, S.E. (2010). Probabilistic assessment of slope stability that considers the spatial variability of soil properties. Journal of Geotechnical and Geoenvironmental Engineering, 136(7), 975-984. https://doi.org/10.1061/(asce)gt.1943-5606.0000309

[18] Ching, J., Phoon, K.-K., \& Chen, Y.-C. (2010). Reducing shear strength uncertainties in clays by multivariate correlations. Canadian Geotechnical Journal, 47(1), 16-33. https://doi.org/10.1139/t09-074

[19] Ching, J., \& Phoon, K.-K. (2012). Modeling parameters of structured clays as a multivariate normal distribution. Canadian Geotechnical Journal, 49(5), 522-545. https://doi.org/10.1139/t2012-015

[20] Müller, R., Larsson, S., \& Spross, J. (2014). Extended multivariate approach for uncertainty reduction in the assessment of undrained shear strength in clays. Canadian Geotechnical Journal, 51(3), 231-245. https://doi.org/10.1139/cgj-2012-0176

[21] Santoso, A.M., Phoon, K.K., \& Tan, T. S. (2013). Estimating strength of stabilized dredged fill using multivariate normal model. Journal of Geotechnical and Geoenvironmental Engineering, 139(11), 19441953. https://doi.org/10.1061/(asce)gt.1943-5606.0000910

\section{Імовірнісний розрахунок за деформаціями масивів з ущільнених розкривних четвертинних порід}

\section{Ю. Винников, М. Харченко, В. Дмитренко, А. Мангура}

Мета. Вивчення впливу напружено-деформованого стану (НДС) масиву на статистичний розкид властивостей деформативності ущільнених розкривних порід. Розробка методики моделювання впливу розкиду випадкових величин (ВВ) характеристик матеріалу основи та аналіз їх НДС моделюванням методом скінченних елементів (МСЕ) та імітаційним моделюванням.

Методика. Використано апробовані методи теорії планування експерименту; методи механіки гірських порід; методи математичної статистики і теорії ймовірності; методи імітаційного моделювання методом Монте-Карло; МСЕ із використанням пружнопластичної моделі для моделювання НДС штучних масивів.

Результати. Отримано статистичні параметри розподілів ВВ розрахункового та граничного опорів ущільнених розкривних порід, осад штампів (фундаментів) на подушках та їх відносної нерівномірності. Встановлено статистичні параметри і закони розподілу осад штампів на підставі чисельного моделювання НДС подушок та імітаційного моделювання методом Монте-Карло. Виявлено, що є ймовірність появи крім лінійної, ще й нелінійної стадії деформування основи, що пояснюється мінливістю характеристик ущільнених порід і випадковою природою навантажень на фундаменти. Встановлено, що ймовірність відмови фундаменту на подушці за I граничним станом допустима, оскільки характеристика безпеки $\beta>3-4$, а за критерієм відносної нерівномірності їх осад на одношаровій подушці сягає $10 \%$ при граничній величині $(\Delta S / L)_{u}=0.002$ і $3 \%-$ при $(\Delta S / L)_{u}=0$ ю004, але для багатошарової подушки ці значення складають відповідно тільки 0.02 і $0.0006 \%$.

Наукова новизна. Встановлено, що визначення деформацій подушок з розкривних четвертинних порід повинно враховувати встановлені закони розподілу фізико-механічних характеристик ущільнених грунтів при чисельній імітації аналітично та методом скінчених елементів із використанням пружно-пластичної моделі.

Практична значимість. Доведена можливість утилізації розкривних четвертинних порід та їх сумішей, використовуючи їх як матеріал грунтових подушок споруд; розроблена методика розрахунку штучних масивів із ущільнених розкривних порід 3 урахуванням статистичних параметрів розподілу їх фізико-механічних характеристик.

Ключові слова: розкривна порід, трунтова подушка, багатофакторний аналіз, кут внутрішнього тертя, питоме зчеплення, модуль деформації, закон розподілу, осадка

\section{Вероятностный расчет по деформациям массивов из уплотненных вскрышных четвертичных пород}

\section{Ю. Винников, М. Харченко, В. Дмитренко, А. Мангура}

Цель. Изучение влияние напряженно-деформированного состояния (НДС) массива на статистический разброс свойств деформативности уплотненных вскрышных пород. Разработка методики моделирования влияния разброса случайных величин (СВ) характеристик материала оснований и анализ их НДС моделированием методом конечных элементов (МКЭ) и имитационным моделированием.

Методика. Использованы апробированные методы теории планирования эксперимента; методы механики горных пород; методы математической статистики и теории вероятности; методы имитационного моделирования методом Монте-Карло; МКЭ с использованием упругопластической модели для моделирования НДС искусственных массивов.

Результаты. Получены статистические параметры распределений СВ расчетного и предельного сопротивлений уплотненных вскрышных пород, осадок штампов (фундаментов) на подушках и их относительной неравномерности. Установлены статистиче- 
ские параметры и законы распределения осадок штампов на основании численного моделирования НДС подушек и имитационного моделирования методом Монте-Карло. Выявлено, что есть вероятность появления кроме линейной, еще и нелинейной стадии деформирования основания, что объясняется изменчивостью характеристик уплотненных пород и случайной природой нагрузок на фундаменты. Установлено, что вероятность отказа фундамента на подушке по I предельному состоянию допустима, так как характеристика безопасности $\beta>3-4$, а по критерию относительной неравномерности их осадок на однослойной подушке достигает $10 \%$ при предельной величине $(\Delta S / L)_{u}=0.002$ и $3 \%$ - при $(\Delta S / L)_{u}=0.004$, но для многослойной подушки эти значения составляют соответственно только 0.02 и $0.0006 \%$.

Научная новизна. Установлено, что определение деформаций подушек из вскрышных четвертичных пород должно учитывать установленные законы распределения физико-механических характеристик уплотненных грунтов при численной имитации аналитически и методом конечных элементов с использованием упругопластической модели.

Практическая значимость. Доказана возможность утилизации вскрышных четвертичных пород и их смесей, используя их в качестве материала грунтовых подушек сооружений; разработана методика расчета искусственных массивов из уплотненных вскрышных пород с учетом статистических параметров распределения их физико-механических характеристик.

Ключевые слова: вскрышная порода, грунтовая подушка, многофакторный анализ, угол внутреннего трения, удельное сцепление, модуль деформачии, закон распределения, осадка

\section{Article info}

Received: 17 February 2020

Accepted: 30 November 2020

Available online: 7 December 2021 